\title{
Erratum to: Variation in 5- hydroxymethylcytosine across human cortex and cerebellum
}

Katie Lunnon ${ }^{1 *}$, Eilis Hannon ${ }^{1}$, Rebecca G.Smith¹, Emma Dempster ${ }^{1}$, Chloe Wong ${ }^{2}$, Joe Burrage ${ }^{1}$, Claire Troakes ${ }^{2}$, Safa Al-Sarraj², Agnieszka Kepa², Leonard Schalkwyk ${ }^{3}$ and Jonathan Mill ${ }^{1,2}$

After the publication of this work [1] it was noticed that the GEO accession number in the data availability section was incorrect. This has now been corrected in the original version of this paper.

\section{Author details}

'University of Exeter Medical School, RILD, University of Exeter, Barrack road, Devon, UK. ${ }^{2}$ Institute of Psychiatry, Psychology and Neuroscience, King's College London, De Crespigny Park, London, UK. ${ }^{3}$ University of Essex, Wivenhoe Park, Colchester CO4 3SQ, UK.

Received: 5 May 2016 Accepted: 5 May 2016

Published online: 17 June 2016

\section{References}

1. Lunnon K, Hannon E, Smith RG, Dempster E, Wong C, Burrage J, et al. Variation in 5-hydroxymethylcytosine across human cortex and cerebellum. Genome Biol. 2016;17:27.

* Correspondence: k.lunnon@exeter.ac.uk

'University of Exeter Medical School, RILD, University of Exeter, Barrack road, Devon, UK

\footnotetext{
Submit your next manuscript to BioMed Central and we will help you at every step:

- We accept pre-submission inquiries

- Our selector tool helps you to find the most relevant journal

- We provide round the clock customer support

- Convenient online submission

- Thorough peer review

- Inclusion in PubMed and all major indexing services

- Maximum visibility for your research
}

Submit your manuscript at www.biomedcentral.com/submit 